\title{
FORMULASI LIMBAH SABUT KELAPA DAN KOTORAN TERNAK MENJADI BIOKOMPOS BAHAN AKTIF Aspergillus sp.
}

\author{
Fitriani $^{1}$, Umrah $^{1^{*}}$, Abdul Rahim Thaha ${ }^{2}$ \\ 1)Jurusan Biologi Fakultas Matematika Dan Ilmu Pengetahuan Alam Untad, Kampus Untad, \\ Jl. Soekarno Hatta km 9, Tondo Palu, Sulawesi Tengah 94118 \\ 2). Jurusan Agroteknologi Fakultas Pertanian Untad \\ Kampus Untad, JI. Soekarno Hatta km 9, Tondo Palu, Sulawesi Tengah 94118 \\ *corresponding author: umrah.mangonrang62@gmail.com
}

\begin{abstract}
The Research on formulation of coconut fiber waste and animal manure into biocomposes (decomposer: Aspergillus sp.) has been carried out in Langaleso Village, Dolo Subdistrict, Sigi Regency, Central Sulawesi, Biotechnology Laboratory of the Department of Biology and the Soil Science Laboratory, Faculty of Agriculture at the University of Tadulako Palu, in March to August 2018. The purpose of this research was to formulate the basic substrate (BS) of coconut fiber waste and animal manure supplementation into biocompost using decomposer: Aspergillus sp. The study was designed in a completely randomized design consisting of five treatments and four replications. The treatments arrangement is a comparison of the base substrate of coconut fiber (BS) with animal manure supplements as follows; P0 (BS 100\%, without supplements), P1 (BS 90\% + supplement 10\%), P2 (BS $80 \%$ + supplement $20 \%$ ), P3 (BS $70 \%$ + supplement $30 \%$ ) and P4 (BS $60 \%$ + supplements $40 \%$ ). Parameters of observation include; physical indicators (aroma, color and texture), biology (fungi identification) and chemistry (analysis of C-organic content and nitrogen). The results showed that the P4 treatment showed the best biocompost quality with physical indicators (compost-smelling aroma, black in color and soft texture), biological indicators (identified as Aspergillus sp and Mucor sp contaminant fungi), chemical indicators (40.5\% C-organic), N 1.36\% and 29.7\%).
\end{abstract}

\section{PENDAHULUAN}

Kelapa merupakan salah satu sumber pendapatan yang sangat penting bagi masyarakat di Sulawesi Tengah. Pertanian kelapa merupakan komoditas tradisional yang secara komersial dapat dihasilkan dalam bentuk kopra, minyak kelapa, makanan segar dan lain-lain. Di Sulawesi Tengah kurang lebih 216.890 ha tanah yang ditanami pohon kelapa (Neeke dkk, 2015). Data perkembangan luas panen produksi dan produktivitas tanaman kelapa di Provinsi Sulawesi Tengah pada tahun 2012 yaitu produksi 209.653 ton dan produktivitas 0.96 ton/ha.

Limbah pertanian yang masih minim dimanfaatkan yaitu limbah sabut kelapa. Menurut Palunkang (2001), pada limbah sabut kelapa mengandung selulosa sebanyak $\pm 43 \%$ sedangkan kandungan lignin nya yakni sebanyak 33\%. Pemanfaatan limbah sabut kelapa masih sangat terbatas namun potensi limbah sabut kelapa yang dihasilkan dari proses industri 
Fitriani, dkk. Biocelebes. Desember. 2019. Volume 13 Nomor 3, Halaman 226-235

sangat banyak dan hanya dibuang atau dibakar sehingga menimbulkan pencemaran.

Serat alami yang banyak diminati untuk obyek penelitian adalah serat sabut kelapa atau yang biasa di kenal dikalangan perdagangan dunia yaitu coco fibre, coir fibre, coir yam, coir mats dan rug. Serat sabut kelapa ini merupakan produksi hasil pengolahan sabut kelapa. Secara tradisional serat sabut kelapa ini hanya dimanfaatkan sebagai bahan pembuatan sapu, keset, tali dan alat rumah tangga lainnya (Lumintang dkk., 2011).

Pupuk yang sering digunakan dalam penelitian yaitu pupuk organik seperti kotoran ternak ayam, kambing dan sapi, kotoran tersebut sering dijumpai di daerah peternakan sehingga dapat dimanfaatkan secara maksimal. Pupuk kandang dari berbagai macam jenis ternak yang mempunyai kualitas berbeda-beda namun mungkin saja memiliki respon terhadap produksi tanaman hijauan yang berbedabeda pula (Satata \& Kusuma, 2014). Salah satu cara pemanfaatan limbah kotoran ternak tersebut dapat dijadikan biokompos yang berguna bagi tanaman. Seperti yang kita ketahui pengomposan memakan waktu yang cukup lama maka perlu dicari solusinya yaitu dengan penambahan dekomposer (mikroorganisme) salah satunya mikroorganisme yang digunakan adalah jamur Aspergillus sp.
Menurut Usha and Padmavati (2013), jamur Aspergillus niger termasuk jamur yang memiliki potensi untuk meningkatkan pertumbuhan tanaman. PGPF sangat bermanfaat bagi tanaman, salah satu jamur yang berpotensi sebagai PGPF yaitu Aspergillus sehingga dapat dimanfaatkan sebagai pupuk hayati (Pandya and Saraf, 2010).

Aspergillus sp. memiliki koloni berwarna hitam gelap, karena konidiofor yang terbentuk sangan cepat dan tumbuh cepat pada media PDA. Konidiafor lembut, panjang dan berwarna bening. Konidium berbentuk bulat dengan permukaannya agak kasar dan berwarna hitam. Vesikel berbentuk agak bulat dan berukuran agak kecil, hifa bersepta dan hialin (Umrah, 2008). Aspergillus sp. merupakan jamur yang bersifat antagonis yang dapat menghambat pettumbuhan jamur patogen selain itu jamur Aspergillus sp. ini juga dikenal sebagai jamur dekomposer.

\section{METODE PENELITIAN}

Penelitian ini dilaksanakan pada bulan Maret sampai September 2018 di Desa Langaleso, Kecamatan Dolo, Kabupaten Sigi dan Laboratorium Bioteknologi Jurusan Biologi FMIPA serta Laboratorium IImu Tanah Pertanian UNTAD, Palu.

\section{ALAT DAN BAHAN}

Alat yang digunakan dalam penelitian ini yaitu pot, seng, timbangan duduk $30 \mathrm{~kg}$, 
Fitriani, dkk. Biocelebes. Desember. 2019. Volume 13 Nomor 3, Halaman 226-235

wadah, karung dan terpal, handskun, masker, mesin granull, $\mathrm{pH}$ meter, gelas ukur $500 \mathrm{ml}$, neraca analitik, alat tulis, cawan petri, Erlenmeyer, cover glass, mikroskop, Bunsen, batang pengaduk, spatula, hot plate, shill, autoclave, jarum ose, labu takar, pipet, beaker, buret, labu ukur, kondensor, pipet ukur dan spektofotometer.

Bahan yang digunakan dalam penelitian ini yaitu limbah sabut kelapa sebagai substrat dasar, jamur Aspergillus sp. dalam bentuk granul dan kotoran ternak (ayam, sapi dan kambing) dan air.

\section{RANCANGAN PENELITIAN}

Penelitian didesain dalam Rancangan Acak Lengap (RAL) dengan empat perlakuan dan tiga kali ulangan. Susunan perlakuan sebagai berikut : $P_{0}$ (Substrat dasar $100 \%$ tanpa suplemen), $\mathrm{P}_{1}$ (Substrat dasar $90 \%+$ suplemen $10 \%), \mathrm{P}_{2}$ (Substrat dasar $80 \%+$ suplemen 20), $P_{3}$ (Substrat dasar $70 \%+$ suplemen $30 \%$ ), $\mathrm{P}_{4}$ (Substrat dasar $60 \%$ + suplemen $40 \%$ ).

Keterangan :

Substrat dasar (Limbah sabut kelapa yang telah melewati ayakan berukuran $4 \mathrm{~mm}$ ).

Suplemen (Campuran antara kotoran ternak ayam, kambing dan sapi (perbandingan 1:1:1) dan Aspergillus sp. sebanyak 500 gram).

\section{PELAKSANAAN PENELITIAN}

Menimbang substrat sesuai perlakuan masing-masing dan melakukan pencampuran substrat dasar dan suplemen kemudian setelah homogen di campurkan jamur Aspergillus sp. dengan suspensi air sebanyak $500 \mathrm{ml}$, setelah itu di masukkan kedalam tempat pengomposan berupa pot berkapasitas $5 \mathrm{~kg}$, diinkubasi selama 30 hari, sambil dilakukan pengamatan setiap lima hari, mulai dari hari ke 0 sampai hari ke 30.

\section{Parameter Fisik}

Pada pengamatan fisik meliputi warna, tekstur, aroma dan suhu. Pengamatan dilakukan pada hari ke 0,5 , 10, 15, 20, 25 dan 30 hari.

\section{a. Aroma}

Pengamatan aroma dilakukan dengan cara mencium bikompos, biokompos yang telah matang akan berbau seperti kompos.

\section{b. Warna}

Pengamatan warna dilakukan dengan cara melihat warna biokompos yang sudah menunjukkan warna hitam menandakan biokompos telah matang.

\section{c. Tekstur}

Pengamatan tekstur dilakukan dengan cara memegang atau meremas biokompos, biokompos yang telah matang teksturnya lembut.

\section{d. Suhu}

Pada waktu pengukuran suhu dilakukan pada hari ke $5,10,15,20$, 25 dan 30 menggunakan thermometer dengan cara 
Fitriani, dkk. Biocelebes. Desember. 2019. Volume 13 Nomor 3, Halaman 226-235

menancapkan thermometer ke dalam biokompos. hasil yang di peroleh akan di catat, semakin lama proses pengomposan maka suhu akan semakin meningkat.

\section{Parameter Biologi}

Parameter pengamatan pada biokompos dilakukan identifikasi jamur.

a. Identifikasi jamur Aspergillus sp.

Pengamatan Aspergillus sp. dilakukan di Laboratorium Bioteknologi jurusan Biologi FMIPA UNTAD, bertujuan untuk mengetahui jenis mikroorganisme apa saja yang terdapat pada proses pengomopsan berlangsung. Pada sampel biokompos dalam sediaan granul, kemudian diambil masing-masing perlakuan biokompos sediaan granul dan dimasukkan kedalam cawan petri sebanyak 5 sediaan granul dan diletakkan secara simentris yang berisi media PSA (Potato Sukrosa Agar) dan diinkubasi selama $2 \times 24$ jam. Selanjutnya dilakukan kultur slide isolat pada biokompos yang diamati pertumbuhan jamurnya.

Prosedur kerja dalam pembuatan mikrokultur untuk mengidentifikasi cendawan secara mikroskopis yaitu menyiapkan cawan petri yang telah diberi tissue steril yang berbentuk bundar didalamnya, lalu aquades steril diteteskan pada bagian tissue untuk menjaga kelembaban yang optimum bagi pertumbuhan jamur tersebut. Kemudian dilettakkan dua buah lidi steril lalu diatas lidi diletakkan sebuah kaca objek yang diberi 1 tetes media PSA dan digoresi isolat jamur yang telah diikubasi selama 2x24 jam menggunakan jarum ose kemudian ditutup dengan kaca penutup. Mikrokultur tersebut diinkubasi dalam suhu ruangan selama 5 hari dilakukan pengamatan menggunakan mikroskop dan pada masa pengamatan selalu menjaga kelembaban dengan menambahkan aquades steril secukupnya apabila tissue mulai mongering. Karakteristik cendawan mengacu pada buku identifikasi Arx, (1981).

\section{Parameter Kimia}

Parameter pengamatan meliputi Analisis C-Organik dan Analisis Nitrogen.

a. Analisi kadar C-Organik

Sampel biokompos ditimbang 1 gr dari masing-masing perlakuan kemudian dihaluskan lalu dimasukkan kedalam labu takar ditambahkan berturut-turut $5 \mathrm{ml}$ larutan $\mathrm{K}_{2} \mathrm{Cr}_{2} \mathrm{O}_{7} 2 \mathrm{~N}$ dan dikocok lalu ditambahkan $7 \mathrm{ml} \mathrm{H}_{2} \mathrm{SO}_{4}$ kocok lagi, dibiarkan selama 30 menit. Kemudian diencerkan dan 
Fitriani, dkk. Biocelebes. Desember. 2019. Volume 13 Nomor 3, Halaman 226-235

dihomogenkan dan dibiarkan selama 1x24 jam lalu diukur menggunakan spektrofotometer.

b. Analisis kadar Nitrogen

Sampel biokompos ditimbang 1 gr dari masing-masing perlakuan, setelah itu ditambahkan dengan bahan katalisator $2 \mathrm{gr}$ dan ditambahkan dengan asam sulfat $\mathrm{H}_{2} \mathrm{SO}_{4} \quad 12,5 \quad \mathrm{ml}$, kemudian dimasukkan kedalam alat destruksi selama 1 jam 25 menit dengan suhu $375^{\circ} \mathrm{C}$ (dihitung mundur sampai lanjut ke proses pendinginan secara otomatis kurang lebih setengah jam) sehingga proses destruksi menghasilkan ammonium dan ditambahkan $\mathrm{NaOH} \quad 35 \%$ lalu didestilasikan selama 5 menit menjadi gas amoniak $\left(\mathrm{NH}_{3}\right)$. Gas amoniak didinginkan lewat pendingin menjadi destilat. Destilat ini ditangkap menjadi asam borat dititrasi dengan asam klorida ( $\mathrm{HCL}$ ) $0,01 \mathrm{~N}$, titik akhir warna biru menjadi merah dan menggunakan blanko sebagai pembanding.

c. $\mathrm{pH}$

Sampel ditimbang sebanyak 10 gr kemudian digerus sampai halus lalu ditambahkan air $90 \mathrm{ml}$ dan diaduk sampai homogen, kemudian diukur $\mathrm{pH}$.

\section{Analisis data}

Data-data yang didapatkan dari hasil pengamatan dilakukan analisis ragam "ANOVA", one way anova, bila mana terjadi perbedaan terhadap masing-masing perlakuan dilakukan uji lanjut Duncan pada taraf $5 \%$.

\section{HASIL DAN PEMBAHASAN}

\section{Parameter Fisik}

Karakteristik perubahan warna substrat pada saat pengomposan sudah mulai terjadi perubahan warna dari berwarna coklat muda menjadi coklat tua. Adanya proses perubahan warna dimulai dari hari ke 10 sedangkan perubahan tekstur terjadi mulai dari hari ke 15 dan tidak berbau.

Pada pengamatan indikator fisik bertujuan untuk melihat perubahan pada pengomposan berupa warna, tekstur, aroma dan suhu. Indikator tersebut mempengaruhi tingkat kematangan pada proses pengomposan.

Hal ini ditunjukkan dengan adanya perubahan fisik substrat dasar limbah sabut kelapa dengan bahan aktif Aspergillus sp. semua perlakuan mulai dari P0, P1, P2, P3 dan P4 yang telah melakukan inkubasi selama 30 hari terlihat mengalami dekomposisi menjadi biokompos. Perubahan warna dasar substat dari warna coklat muda 
Fitriani, dkk. Biocelebes. Desember. 2019. Volume 13 Nomor 3, Halaman 226-235

menjadi hitam hal ini disebabkan karena adanya proses dekomposisi dalam pengomposan (Sudirja, 2005). Pada perubahan fisik tekstur dari kasar menjadi lembut dan bersifat remah apabila di pegang. Pada aroma biokompos biasanya tidak berbau dan memiliki aroma seperti kompos, hasil yang didapatkan bahwa rata-rata memiliki aroma seperti bau kompos. Karakteristik aroma, warna dan tekstur biokompos mendekati kriteria standar kualitas kompos SNI 19-7030-2004 (Badan Standar Nasional Indonesia, 2011).

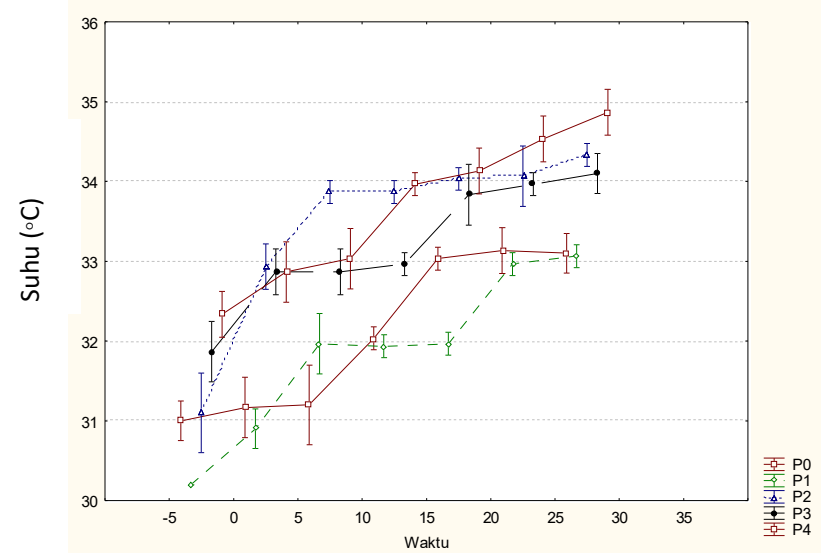

Gambar 1 Rata-rata suhu biokompos selama masa inkubasi.

Pengamatan suhu sangat
berpengaruh terhadap proses
pengomposan karena suhu merupakan
salah satu indikator dalam mengurai
bahan organik dan suhu juga dapat

menentukan aktivitas mikroba. Dari hasil pengamatan yang dilakukan dapat dilihat bahwa terjadi perubahan pada suhu. Pada hari ke 0 pengomposan suhu yang di hasilkan masih normal akan tetapi pada hari ke 5 , ke 10 , ke 15 , ke 20 , ke 25 dan ke 30 suhu terlihat semakin naik hal ini dikarenakan adanya aktivitas mikroorganisme memperbanyak diri dalam mendekomposisi bahan organik sehingga pertumbuhan dan aktivitas mikroba merombak sangat intensif (Sutedjo dkk, 1991).

\section{Parameter Biologi}

Hasil yang didapatkan terdapat 2 jenis jamur yang terdapat pada proses pengomposan berlangsung yaitu jamur Aspergillus sp. dan Mucor sp. Gambar mikroskopis sebagai berikut :
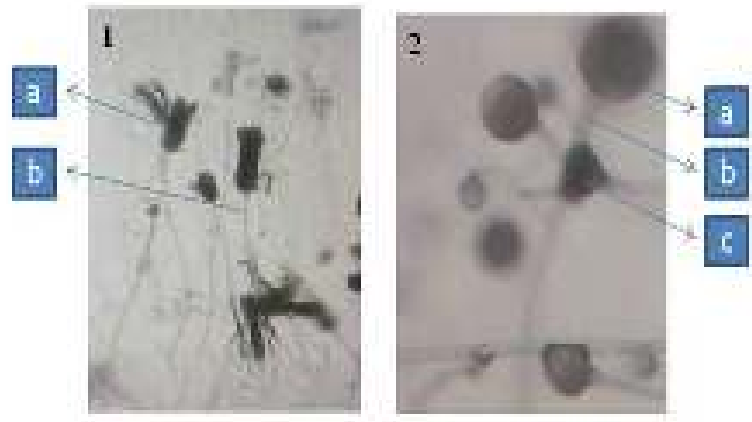

Gambar 2 Jamur Aspergillus sp. dan Mucor sp.

Kererangan : 1 jamur Aspergillus sp (a) konidia, (b) konidiofor, 2 jamur Mucor sp. (a) spora, (b) sporangium, (c) Sporangiosfor

Pembuatan biokompos dapat berjalan dengan cepat karena menggunakan mikroorganisme. (Purwantisari dan Hastuti, 
Fitriani, dkk. Biocelebes. Desember. 2019. Volume 13 Nomor 3, Halaman 226-235

2009), dimana mikroorganisme yang di gunakan yaitu jamur Aspergillus sp., Aspergillus dapat menghasilkan senyawa IAA yang dapat membantu pertumbuhan dan perkembangan pada tumbuhan (Ahmad et al., 2005). Pada pembuatan biokompos ini juga didapatkan jamur Mucor sp. dimana jamur Mucor sp. ini memiliki peran dalam merombak bahan organik. Jadi dapat dilihat bahwa semua mikroorganisme dapat bekerja bersinergi dalam mendekomposisi bahan organik.

\section{Parameter Kimia}

a. Kandungan C-Organik

Pemberian substrat dasar
limbah sabut kelapa dapat
meningkatkan kandungan C-
Organik, dapat dilihat adanya
perbedaan nyata pada
pembuatan biokompos tersebut.

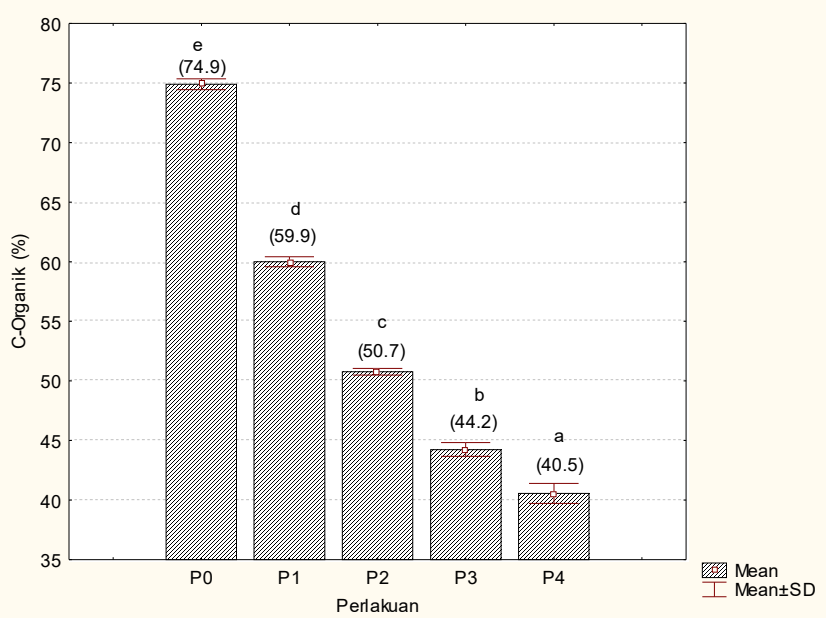

Gambar $\begin{gathered}3 \\ \text { formulasi biokompos }\end{gathered}$
C-Organik merupakan unsur terpenting bagi tanaman, karena dapat menambah bahan organik dalam tanah. Hasil yang didapatkan menunjukkan bahwa penambahan limbah sabut kelapa dapat meningkatkan kandungan C-Organik pada proses pengomposan, dapat dilihat pada nilai tertinggi yang diperoleh pada perlakuan PO (kontrol) yaitu $74,9 \%$ sedangkan nilai terendah pada perlakuan P4 yaitu 40,5\%. Faktor yang mempengaruhi tingginya kandungan $\mathrm{C}$ Organik tersebut dipengaruhi oleh dekomposer yang mengurai bahan organik yang sangat efektif dalam mengurai unsur karbon. Karbon merupakan sumber energi yang memiliki $50 \%$ dari bagian massa sel mikroba (Kardin, 2005).

\section{b. Kandungan Nitrogen}

Hasil analisis $\mathrm{N}$ dapat dilihat pada Gambar 2. Berdasarkan analisis sidik ragam, setiap perlakuan memiliki kandungan yang berbeda nyata. Hasil uji berganda "Duncan" analisis kandungan Nitrogen tertinggi di peroleh pada perlakuan $\mathrm{P} 4$ yaitu $1.36 \%$ sedangkan nilai terendah pada perlakuan PO (kontrol) yaitu $0.94 \%$ 
Fitriani, dkk. Biocelebes. Desember. 2019. Volume 13 Nomor 3, Halaman 226-235

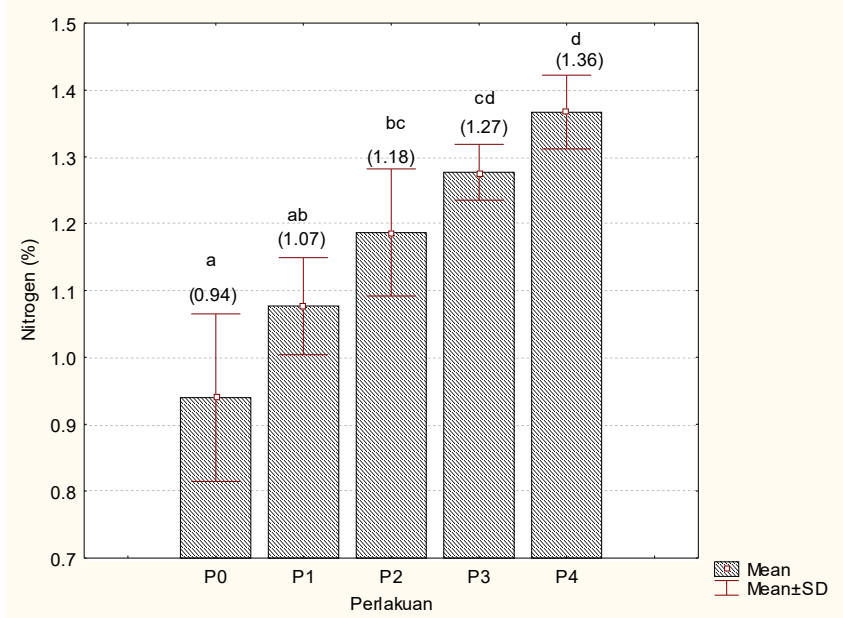

Gambar 4 Kandungan Nitrogen formulasi bikompos.

Semakin banyak pemberian substrat dasar limbah sabut kelapa dapat menurunkan kandungan Nitrogen namun semakin banyak pemberian suplemennya maka semakin tinggi kandungan Nitrogennya, hal ini dapat dilihat pada nilai tertinggi yang diperoleh pada perlakuan P4 $1,36 \%$ sedangkan nilai terendah pada perlakuan P0 (kontrol) 0,94\%. Nilai N yang mengalami peningkatan atau penurunan selama proses pengomposan dikarenakan nilai $\mathrm{N}$ bersifat fluktuatif (Widarti $\mathrm{dkk}, 2015$ ). Peningkatan kadar $\mathrm{N}$ pada proses pengomposan dikarenakan oleh meningkatnya jumlah populasi mikroba dalam mendekomposisi kompos, kandungan $\mathrm{N}$ sangat dibutuhkan oleh tanaman sebagai penyusun asam amino, protein dan komponen lainnya, sedangkan rendahnya nilai $\mathrm{N}$ dikarenakan kurangnya aktivitas mikroba dalammendekomposisi kompos.

\section{c. C/N Rasio}

Rasio C/N merupakan parameter dalam pengomposan. Berdasarkan analisis sidik ragam setiap perlakuan memiliki kandungan rasio $\mathrm{C} / \mathrm{N}$ yang berbeda nyata.

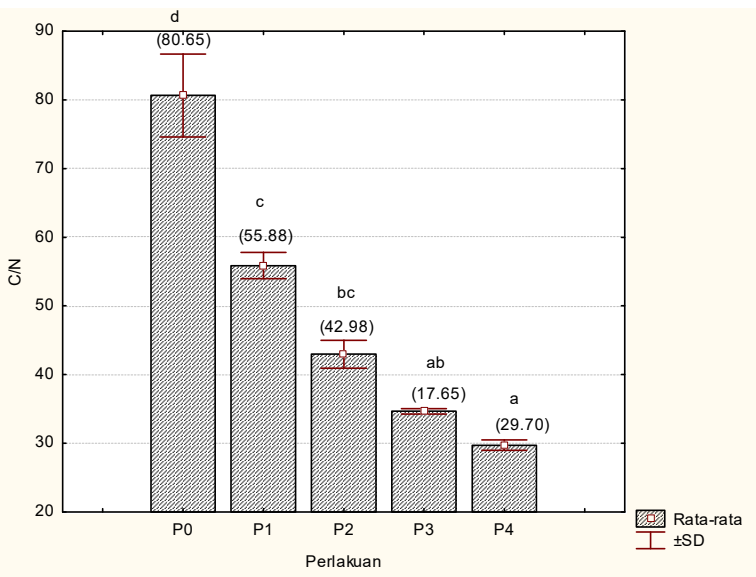

Hasil penelitian menunjukkan bahwa $\mathrm{C} / \mathrm{N}$ rasio dapat digunakan pada tanaman karena pada beberapa perlakuan memiliki nilai $\mathrm{C} / \mathrm{N}$ rasio $25-50$, hal ini sesuai dengan pendapat Tchobanonglous et al., (1993). Pada perlakuan yang memiliki nilai rasio $\mathrm{C} / \mathrm{N}$ tinggi dipengaruhi oleh aktivitas biologi mikroorganisme yang sangat kurang (Djuarnani, 2005).

d. $\mathrm{pH}$

Hasil analisis menunjukkan bahwa pemberian substrat dasar limbah sabut kelapa berpengaruh terhadap hasil pengukuran $\mathrm{pH}$ selama proses fermentasi pengomposan. Pada hari ke 0 rata-rata $\mathrm{pH}$ yang diperoleh yaitu 7-7,1 sedangkan $\mathrm{pH}$ pada biokompos disetiap 
Fitriani, dkk. Biocelebes. Desember. 2019. Volume 13 Nomor 3, Halaman 226-235

5 hari mengalami kenaikan hingga pada hari ke 25 dan hari ke $30 \mathrm{pH}$ dapat mencapai 7,6-7,7.

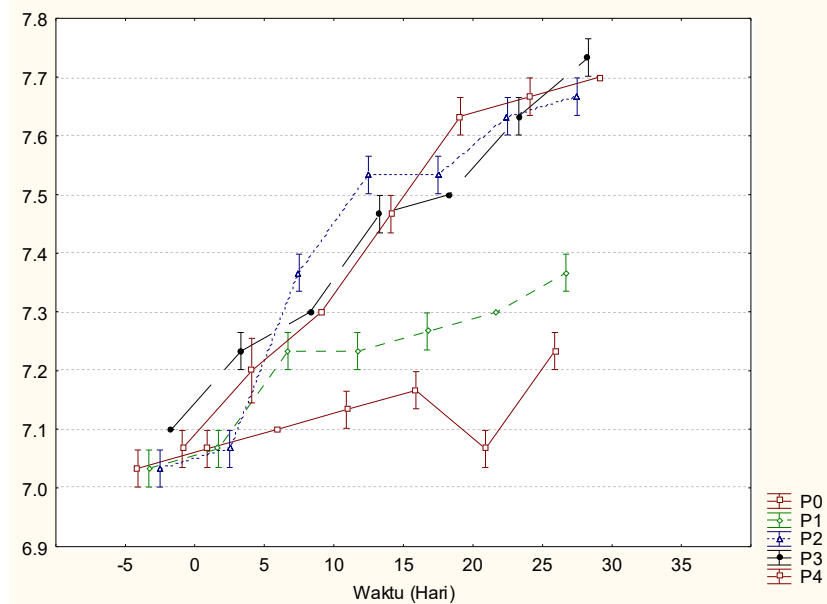

Gambar 5 Rata-rata $\mathrm{pH}$ bikompos selama masa inkubasi.

Aktivitas mikroba dalam proses pengomposan dapat dilihat pada perubahan $\mathrm{pH}$. Pada hari ke 0 rata-rata $\mathrm{pH}$ yang diperoleh yaitu 7-7,1 sedangkan $\mathrm{pH}$ pada biokompos disetiap 5 hari mengalami kenaikan hingga pada hari ke 25 dan hari ke $30 \mathrm{pH}$ dapat mencapai 7,6-7,7. Pada prroses ini menunjukkan bahwa aktivitas mikroorganisme memperbanyak diri meningkat dan mengubah bahan organic menjadi asam organic. Nilai $\mathrm{pH}$ pada pengomposan berpengaruh terhadap pertumbuhan bakteri. Kenaikan $\mathrm{pH}$ disebabkan karena terjadinya penguraian protein menjadi ammonia (NH 3) (Widarti, 2015).

\section{DAFTAR PUSTAKA}

Ahmad F, Ahmad I and Khan SM. (2005). Indole acetic acid production by the indigenous isolates of Azotobacter and fluorescent Pseudomonas in the presence and absence of tryptophan. Turkish Journal of Biology. 29. 29-34.

Arx, J. A. V. (1981). The genera of fungi sporulating in pure culture. Germany: J.Cramer. 1-424.

Badan Standarisasi Nasional Indonesia (BSNI 2004), (2011). Spesifikasi Kompos dari Sampah Organik Domestik. SNI 1970302004.

Djuarnani, Nan. (2005). Cara Cepat Membuat Kompos. Jakarta: Agromedia Pustaka.

Kardin, D. 2005. Teknologi Kompos. www.diperta.jabarprov.go.id. Diakses [20 September 2011]

Lumintang, R., C., A., Soenoko, R., dan Wahyudi, S., (2011). Komposit hibrid polyester berpenguat serbuk batang dan serat sabut kelapa. Rekayasa Mesin, 2(2), 145-153.

Neeke, H., Antara, M., dan Laapo, A., (2015). Analisis pendapatan dan nilai tambah kelapa menjadi kopra di desa bolubung kecamatan bulagi utara kabupaten banggai kepulauan. Agrotekbis, 3(4), 532-542.

Pandya $U$ and Saraf $M$, Application of fungi as a biocontrol agent and their biofertilizers potential in agriculture, Journal of Advances in Developmental Research, 1 (1): 90-99, (2010).

Palungkun, R. (2001). Aneka Produk Olahan Kelapa. Cetakan VIII. Jakarta: Penebar Swadaya. 
Fitriani, dkk. Biocelebes. Desember. 2019. Volume 13 Nomor 3, Halaman 226-235

Purwantisari, S., dan Hastuti, R. B (2009).

Uji Antagonisme Jamur Patogen

Phytopthora infestrans Penyebab

Penyakit Busuk Daun dan Umbi

Tanaman Kentang dengan

Menggunakan Trichoderma sp. Isolat Lokal. Bioma, 11(1), 24-32.

Satata, B., dan Kusuma, M. E. (2014). Pengaruh Tiga Jenis Pupuk Kotoran Ternak ( Sapi , Ayam , dan Kambing ) Terhadap Pertumbuhan dan Produksi Rumput Brachiaria Humidicola. Jurnal IImu Hewani Tropika, 3(2), 5-9.

Sudirja, R., Solihin, M. A., Rosniawaty, S. (2005). Pengaruh kompos kulit buah kakao dan kascing terhadap perbaikan beberapa sifat kimia Fluventic Eutrudepts. Bandung: Lembaga Penelitian Universitas Padjadjaran.

Sutedjo, M. M., Kartasapoetra, A. G., Sastroatmodjo. R. D. S., (1991). Mikrobiologi Tanah. Jakarta: Rin Eka Cipta.

Tchobanonglous, G., H. Theisen and S. Vigil. (1993). Integrated solid waste management, engineering principles and management issues. USA: Mc Graw hill Inc.

Umrah, (2008). Identifikasi Jamur Aspergillus niger Asal Lahan Perkebunan Kakao Rakyat, Laporan Penelitian Mandiri, Fakultas Pertanian, Universitas Tadulako.

Usha, S., And Padmavathi P. (2013). Effect of plant growth promoting microorganisms from rhizosphere of Piper nigrum L. International Journal Of Pharma And Bio Sciences. 4(1). $835-846$.

Widarti, B. N., Wardhini, K. W., dan Sarwono, E. (2015). Pengaruh Rasio C/N Bahan Baku Pada Pembuatan Kompos Dari Kubis dan Kulit Pisang. Integrasi Proses, 5(2). 75-8 